\title{
Biovolume and biomass estimates of key diatoms in the Southern Ocean
}

\author{
Véronique Cornet-Barthaux*, Leanne Armand, Bernard Quéguiner \\ Aix-Marseille Université, CNRS, LOB-UMR 6535, Laboratoire d'Océanographie et de Biogéochimie, \\ OSU/Centre d'Océanologie de Marseille, 13288 Marseille, France
}

\begin{abstract}
Linear measurements of 31 Southern Ocean diatom species or genus groupings are presented and used in the derivation of species-specific biovolume, biomass and surface to volume ratios. Species measurements are in tune with summarised values in the literature and range from 2.6 to $2296 \mu \mathrm{m}$ in length and 8.5 to $140 \mu \mathrm{m}$ in diameter. Average cell volume ranged from 63 to $1.43 \times$ $10^{5} \mathrm{\mu m}^{3}$ and biomass from 10 to $3686 \mathrm{pg} \mathrm{C} \mathrm{cell}^{-1}$, the values being smallest in pennate shaped species and greatest in cylindrical centrics. The 31 species can be divided into 7 small, 12 intermediate and 12 large biomass contributors based on their cell volume and/or their surface to volume ratio. Carbon biomass estimates from biovolume equations are discussed and suggest that future work including large Southern Ocean species is warranted. Species-specific biomass values reported here should serve as a baseline for future analyses of major diatom carbon contributors in the generally high nutrient, low chlorophyll Southern Ocean.
\end{abstract}

KEY WORDS: Diatoms $\cdot$ Size measurements $\cdot$ Cell biovolume $\cdot$ Carbon biomass $\cdot$ Kerguelen Plateau

\section{INTRODUCTION}

Diatoms are a dominant group of the Southern Ocean phytoplankton community and marine ecosystem (Hasle 1969, Jacques et al. 1979, Kopczynska et al. 1986, El-Sayed \& Fryxell 1993) and their carbon biomass (in both absolute and relative terms) is a fundamental parameter in determining their quantitative role in marine biogeochemical, carbon and silica budgets. The most widely used measurement for estimating phytoplankton biomass is that of in situ chlorophyll fluorescence or the fluorometric measurement of extracted chlorophyll (e.g. Garibotti et al. 2003). These methods provide poor information on the community structure and relative contribution in terms of carbon biomass for the different phytoplanktonic groups and even less so for the species in these groups (Havskum et al. 2004). Analyses of phytosynthetic and photoprotective pigments, called marker pigments, enable the identification and quantification of the major microalgae classes or genera (e.g. Prochlorococcus), but do not differentiate the phytoplankton to species level. Determination of the pigment marker fucoxanthin is used to define 'diatoms' in such analyses, but also includes the presence of pyremnesiophytes, chrysophytes, raphidophytes and certain dinoflagellates (Jeffrey \& Hallegraeff 1980, 1987, Klein \& Sournia 1987, Wright et al. 1991, Jeffrey et al. 2005). The counting of cells by microscopy provides the most comprehensive inventory of a sample's taxa. However, diatoms demonstrate a wide range of shapes and sizes, thus cell counts exclusively are an inadequate measure of relative diatom biomass and conversion to biovolume is necessary (Mullin et al. 1966, Strathmann 1967).

Phytoplankton biovolume and/or biomass for Southern Ocean species are rarely reported (Kang \& Fryxell 1993, Ahn et al. 1997, Agustí \& Duarte 2000, Moro et al. 2000, Kang et al. 2001, Pakhomov et al. 2001). More frequently, biomass is summarised as a pooled phytoplankton value and placed in comparison with species abundance data for various study sites or regions (e.g. Bathmann et al. 1997, Kopczynska \& Fiala 2003, Gari- 
botti et al. 2005, Krell et al. 2005). Such assessments fall short of attributing the major carbon biomass contributors by confounding dominant relative abundance contributions irrespective of size and, therefore, carbon contribution.

The objective of the present study was to estimate the cell carbon biomass from the majority of Permanently Open Ocean Zone diatoms in the vicinity of Kerguelen Island, in the Indian sector of the Southern Ocean (Fig. 1). Studies in, around and from the sediments of the Kerguelen Plateau have shown little indication of regionalised diatom endemism in this chlorophyll productivity hot-spot (Sullivan et al. 1993), with the exception of a coastal benthic community linked to the islands themselves that stands apart from the open ocean community (from O'Meara 1877 and Manguin 1954, to recent studies of Blain et al. 2001, Riaux-Gobin \& Romero 2003, Crosta et al. 2005, and L. K. Armand et al. unpubl.). The accuracy of the biomass estimate is essential for the assessment of the diatom carbon contribution in the surface waters in and around the naturally iron-fertilized Kerguelen region (Blain \& Quéguiner 2005, Blain et al. 2007). Here we document

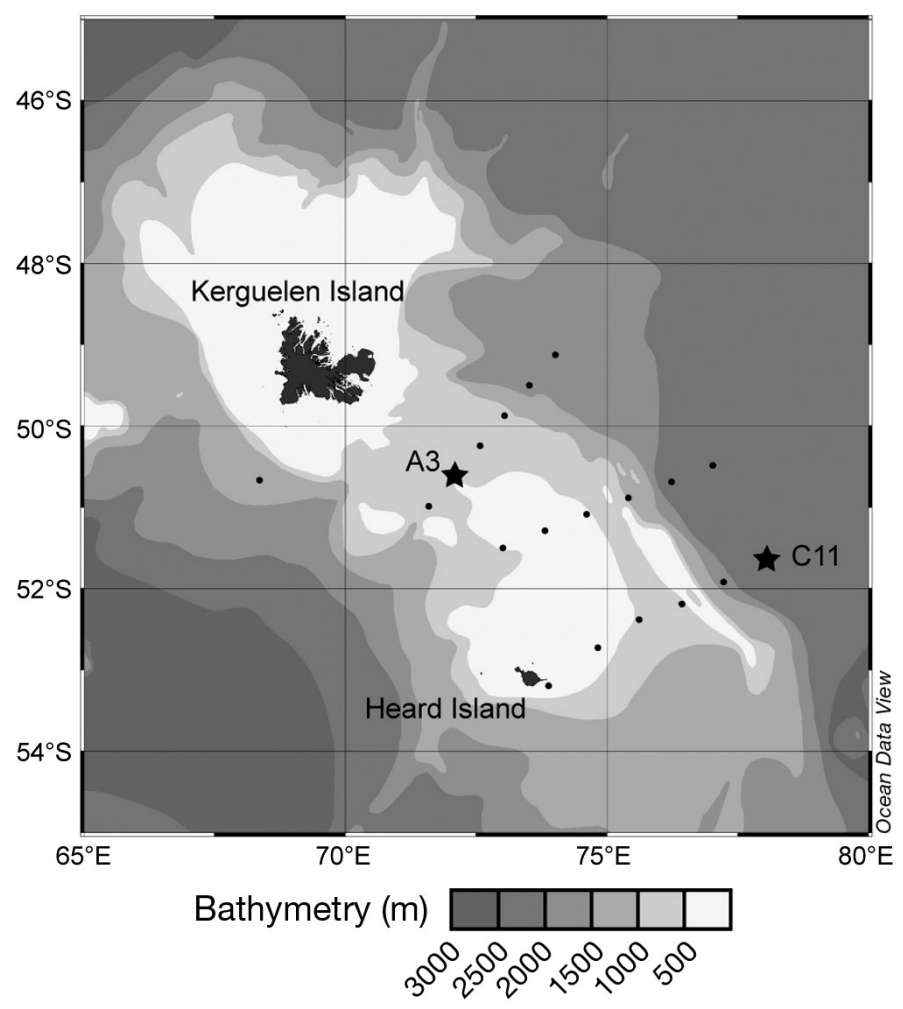

Fig. 1. Position of KEOPS (KErguelen Ocean and Plateau compared Study) Stns A3 and C11 ( $\star$ ). Small black dots represent other sites in the KEOPS program not discussed in this study. Table 1 details the locations and environmental conditions of each site over sampling times. Plotted using ODV (Ocean Data View, see http://odv.awi.de) microscopic size measurements, their conversion to cell biovolumes and subsequent translation to carbon biomass and surface to volume ratios. The methodology and results presented during our study will be useful for future Southern Ocean diatom analysis both from a general taxonomic perspective and also as a baseline for future biogeochemical investigations requiring specific and realistic biomass estimates based on specific taxa.

\section{MATERIALS AND METHODS}

Sample collection. Samples for analyses of phytoplankton abundance and biomass were collected as part of the KEOPS (KErguelen Ocean and Plateau compared Study) research program during the austral summer (January to February 2005) over the Kerguelen Plateau in the Southern Ocean (Blain \& Quéguiner 2005, Blain et al. 2007). Two representative stations (A3, within the plateau bloom region; and C11, out of bloom region) were investigated in detail and represent the data presented in this study (Fig. 1). The stations were repeatedly visited, 4 and 3 times, respectively, over a month long period. The samples are considered to have captured the same station populations at various stages of bloom and cell division cycles. Visits to Stns A3 and C11 were set, and then subsequently tracked, based on daily MODIS satellite imagery of the chlorophyll a bloom at Stn A3 and the lack of a bloom at Stn C11. The physical oceanographic analysis of the study is found in Y. H. Park et al. (unpubl.) and indicates that the same water masses were sampled respectively at each site. Both have different sources and are assumed to retain clearly different evolving populations. General environmental parameters support the differing sites and conditions (Table 1). Environmental conditions and the evolving diatom communities are discussed in L. K. Armand et al. (unpubl.).

Discrete water samples were taken at various depths within the upper $150 \mathrm{~m}$ of the water column from 24 Niskin bottles on a rosette frame equipped with a Sea Bird SBE-911 plus CTD sensor. Aliquots of $125 \mathrm{ml}$ were preserved with acid Lugol's iodine solution (final concentration of $0.32 \%$ ) and stored in coloured glass bottles, in the dark and at room temperature, until their analysis on return to the laboratory.

Diatom evaluation. Diatoms were identified to the lowest possible taxonomic level, enumerated, and their linear dimensions documented under a Nikon Eclipse TE2000-E inverted microscope equipped with phasecontrast, a long distance condenser and a $12 \mathrm{~V}, 100 \mathrm{~W}$ halogen light source. The video system consisted of a Nikon DS-U1 camera control unit and a Nikon DS-5Mc 
Table 1. Sample locations and mean physical values in surface waters from Stns A3 and C11, sampled by CTD on multiple occasions (indicated by the number after the station identifier). Sources: mean sea-surface temperature and salinity and photosynthetically available radiation (PAR) from KEOPS community data; mean chlorophyll a and fucoxanthin (Fuco.) data from J. Uitz et al. (unpubl.)

\begin{tabular}{|c|c|c|c|c|c|c|c|c|c|}
\hline Stn & $\begin{array}{c}\text { Sample } \\
\text { no. }\end{array}$ & $\begin{array}{c}\text { Date } \\
\text { (d/mo/yr) }\end{array}$ & $\begin{array}{l}\text { Lat. } \\
\left({ }^{\circ} \mathrm{S}\right)\end{array}$ & $\begin{array}{l}\text { Long. } \\
\left({ }^{\circ} \mathrm{E}\right)\end{array}$ & $\begin{array}{l}\text { Sea-surface } \\
\text { temp. }\left({ }^{\circ} \mathrm{C}\right)\end{array}$ & $\begin{array}{l}\text { Sea-surface } \\
\text { salinity }\end{array}$ & $\begin{array}{c}\text { Total } \\
\operatorname{chl} a\left(\mu \mathrm{g}^{-1}\right)\end{array}$ & $\begin{array}{l}\text { Fuco. } \\
\left(\mu \mathrm{g} \mathrm{l}^{-1}\right)\end{array}$ & $\begin{array}{c}1 \% \text { PAR } \\
\text { depth (m) }\end{array}$ \\
\hline A3-1 & CTD 007 & 19/1/05 & $50^{\circ} 37.80^{\prime}$ & $72^{\circ} 04.60^{\prime}$ & 3.5 & 33.56 & 0.94 & 0.56 & 41.8 \\
\hline A3-3 & CTD 031 & $24 / 1 / 05$ & $50^{\circ} 41.30^{\prime}$ & $71^{\circ} 59.90^{\prime}$ & 3.68 & 33.86 & 0.97 & 0.63 & 39.9 \\
\hline A3-4 & CTD 076 & $4 / 2 / 05$ & $50^{\circ} 39.50^{\prime}$ & $72^{\circ} 04.00^{\prime}$ & 3.58 & 33.86 & 1.34 & 0.51 & 46.0 \\
\hline A3-5 & CTD 112 & $12 / 2 / 05$ & $50^{\circ} 37.79^{\prime}$ & $72^{\circ} 05.29^{\prime}$ & 3.84 & 33.88 & 1.09 & 0.59 & 43.8 \\
\hline C11-1 & CTD 040 & $26 / 1 / 05$ & $51^{\circ} 37.50^{\prime}$ & $77^{\circ} 57.40^{\prime}$ & 1.91 & 33.80 & 0.22 & 0.10 & 97.5 \\
\hline C11-2 & CTD 045 & $28 / 1 / 05$ & $51^{\circ} 38.80^{\prime}$ & $78^{\circ} 00.10^{\prime}$ & 1.72 & 33.79 & 0.17 & 0.09 & 97.5 \\
\hline C11-3 & CTD 082 & $6 / 2 / 05$ & $51^{\circ} 39.00^{\prime}$ & $78^{\circ} 00.00^{\prime}$ & 1.91 & 33.80 & 0.16 & 0.07 & 122.9 \\
\hline
\end{tabular}

cooled camera head. Diatoms were enumerated from a $10 \mathrm{ml}$ sub-sample after settling for $24 \mathrm{~h}$ in an Utermöhl style counting chamber. Counts were made from the entire chamber following the Utermöhl methodology (Hasle 1978). This data set is discussed in detail elsewhere (Blain et al. 2007, L. K. Armand et al. unpubl. a). Taxonomy followed major modern concepts detailed in Hasle \& Syvertsen (1997). Additional taxonomic references used are detailed in Appendix 1 (available as Supplementary Material online at www.int-res.com/articles/suppl/a048p295_app.pdf). Several taxa groupings are made due to the difficulty in differentiating some species in their natural state. We grouped all small Chaetoceros Hyalochaetae species together although the dominant contributor was Chaetoceros socialis. Chaetoceros Hyalochaetae resting spores are poorly known to species level and so grouped. The Chaetoceros bulbosum complex (Ehrenberg) Heiden includes all synonyms of $C$. atlanticus Cleve, C. atlanticus var. neapolitana (Schroder) Hustedt and C. bulbosum Ehrenberg. Fragilariopsis rhombica and F. separanda could not be separated in living material and so were grouped. Membraneis spp. represent a genus that was often undergoing division in our material, making exact species identification difficult. Species in this category are represented largely by Membraneis imposter and M. challengeri. Navicula directa and a smaller unidentified Navicula species represent the category Navicula spp. The genus Pseudo-nitzschia was divided into 2 categories based on the shape and perceived width of the transapical axis above and below $5 \mu \mathrm{m}$. Specimens with a transapical axis $>5 \mu \mathrm{m}$ are dominated by the species $P$. heimii, whereas species encountered in the $<5 \mu \mathrm{m}$ category represent $P$. lineola, $P$. turgidula and $P$. subcurvata. Chained pennates predominately in girdle view are classified as 'other pennates'

For each sample, cells assumed to be alive when collected were measured from random transects scanned across the counting chamber, at $100 \times, 200 \times$ or $400 \times$ magnification, according to cell size and until 20 to $>100$ specimens had been measured for each species. Rare species (i.e. $<20$ specimens observed per species) were measured, but are not detailed in this study. Measurements were made from the monitor images with the image analysis software LUCIA-G version 5 (Laboratory Imaging); the precision of measurement was determined to be generally less than $0.5 \mu \mathrm{m}$ for measurements between 5 and $100 \mu \mathrm{m}$.

Volume, biomass and surface to volume ratio estimates. Biovolume estimates were made from the mean of linear dimensions using the appropriate geometric formulae reflecting the shape of the cell (Hillebrand et al. 1999). We determined the coefficient of variance percentages $(\mathrm{CV} \%=\mathrm{SD} /$ mean $\times 100)$ on cell volume to provide an indication of the population variability for volume, where a low percentage indicates small differences between calculated volumes and vice versa. The carbon content of diatoms was calculated from cellular biovolume according to the corrected equation of Eppley et al. (1970; corrected in Anonymous 1974, Smayda 1978):

$\log _{10} \mathrm{C}(\mathrm{pg})=0.76 \log _{10}\left[\right.$ cell volume $\left.\left(\mu \mathrm{m}^{3}\right)\right]-0.352$ (1)

Other carbon to volume relationships have been established and are presented elsewhere (Parsons et al. 1961, Mullin et al. 1966, Moal et al. 1987, Montagnes et al. 1994), but these methods mix several groups of phytoplankton and do not consider diatoms alone. Menden-Deuer \& Lessard (2000) combined data from Strathmann (1967) and diatom data from the authors cited above, thus determining new conversion factors for volume to carbon biomass for diatoms both above and below a biovolume value of $3000 \mu^{3}$ (hereafter referred to as the MDL equations). For reasons divulged in the discussion, we did not follow the MDL equations for carbon biomass estimation in this work, which in some cases will result in an overestimation of a larger-celled species biomass under the Eppley et al. (1970) equation due to their decreased carbon density. 
We did not correct for inert cell structures, such as vacuoles (Sicko-Goad et al. 1984, Snoeijs et al. 2002), in our biovolume estimates, as the proportions of a vacuole differ phylogenetically and physiologically (Hillebrand et al. 1999). The fact that the vacuole is simply not a box within a box (Sicko-Goad et al. 1984) means that the accuracy of vacuole volume can only be achieved when the proportions for every species of every sample are sampled. Additional complications in the estimation of cell volume result from the type and duration of fixation (Menden-Deuer et al. 2001). This presented a considerable complication to our study, taking into account the intrinsic errors of successive steps: counts, linear measurements and cell shape designation. Thus, this extra work in defining vacuole size and absolute cell volume specimen by specimen was not undertaken and presents an acknowledged assumption in our biomass calculations.

Mean surface to volume ratios $(S / V$ ratio) were calculated using the Biovol program of Kirschtel (1992 and BIOVOL Ver. 2.1, available at www.msu.edu/ rirschte/biovol/index.html) with the exception of the rectangular forms. The $S / V$ ratio for a rectangular form is thus determined from these calculations:

$$
S=2 a b+2 b c+2 a c \text { and } V=a b c
$$

where $a, b$ and $c$ are, respectively, apical, transapical and pervalvar sections.

\section{RESULTS}

\section{Linear measurements}

All data presented here are based on size measurements performed on cells from KEOPS process stations A3 and C11. A total of 31 species or taxa groups among the 50 identified in this larger study were measured. Linear measurements (the range and mean of diameter, pervalvar, apical, and transapical axes, where appropriate) for 31 diatom species or categories are presented in Table 2. The largest centric diatoms encountered in the present study were Asteromphalus hookeri (140 $\mu$ m diameter) and Thalassiosira lentiginosa (129 $\mu \mathrm{m}$ diameter), although rare Thalassiosira tumida and Coscinodiscus spp. (not reported here) did obtain diameters of 170 and $134 \mu \mathrm{m}$, respectively. The longest diatom was Thalassio-thrix antarctica at $2296 \mu \mathrm{m}$, although chains of Eucampia antarctica v. antarctica and Pseudo-nitzschia spp. were observed as equally long in many samples. The smallest diatom encountered was Fragilariopsis pseudonana, with a mean size of $3.2,6.6$ and $3.8 \mu \mathrm{m}$ for the pervalvar, apical and transapical axes, respectively.
Measuring the third dimension of a diatom is a problem under light microscopy due to the nature of diatom cells lying in a single, commonly valvar, plane. In general, we could not determine all 3 dimensions from the same cell, and obtaining a mean value for the missing dimension via the literature proved difficult as only range values are documented. To estimate the second dimension in centric diatoms with a discoid shape, e.g. Azpeitia spp., Asteromphalus spp., Thalassiosira spp., we determined a mean pervalvar axis to mean diameter ratio on 14 Thalassiosira gracilis specimens (result 0.68) and confirmed the ratio values against measurements in Kang et al. (2001). For pennate diatoms a subset of Fragilariopsis kerguelensis and Fragilariopsis pseudonana specimens were measured in valve view and in broad girdle view (Table 3). We determined the mean ratio of pervalvar to transapical axis and used this ratio (0.9) to estimate the third dimension in volume calculations for other elliptic or elongate pennates.

\section{Cell volume, carbon content and surface to volume ratios}

Biovolume and biomass calculations for each major species or taxa grouping are reported in Table 2. Species-specific average cell volume ranged from 63 to $1.43 \times 10^{5} \mathrm{\mu m}^{3}$ and biomass from 10 to $3686 \mathrm{pg} \mathrm{C} \mathrm{cell}^{-1}$. Minimum carbon biomass estimates were obtained from the pennate diatoms Fragilariopsis pseudonana (63 $\mu^{3}$ and $10 \mathrm{pg} \mathrm{C}$ cell $^{-1}$ ) and Cylindrotheca closterium (125 $\mathrm{\mu m}^{3}$ and $17 \mathrm{pg} \mathrm{C}$ cell $^{-1}$ ). Maximum carbon values were observed in the centric diatom Proboscia alata $\left(1.43 \times 10^{5} \mathrm{\mu m}^{3}\right.$ and $\left.3686 \mathrm{pg} \mathrm{C} \mathrm{cell}^{-1}\right)$, whereas the pennate diatoms Thalassiothrix antarctica and Membraneis spp. also attained elevated carbon values of 3556 and $3225 \mathrm{pg} \mathrm{C}$ cell $^{-1}$, respectively. The 3 smallest species encountered in our samples were calculated with the 3 largest $S$ / $V$ ratios (Cylindrotheca closterium, 2.214; Fragilariopsis pseudonana, 1.481; and Thalassionema nitzschioides v. nitzschioides, 1.261). Unsurprisingly, larger species dominated the smallest ratio values, with Thalassiosira lentiginosa being the smallest recorded (0.116, Table 2$)$. The average $S$ / $V$ ratio for the 31 major species is 0.53 ; however, approximately $2 / 3$ of the species documented here have $S / V$ ratios less than this mean, and in the majority of these cases their ratios fall between 0.1 and 0.3 .

The coefficients of variation $(\mathrm{CV})$ for biovolume range between 15.7 and $116.2 \%$; this heterogeneity is in accordance with the study of Menden-Deuer et al. (2001), who reported a volume CV for Lugol's fixed cells between 5 and $122 \%$. Of the 31 species and taxa groups observed, the majority of \%CV values were $<60 \%$, with the exception of Thalassiosira lentiginosa, 


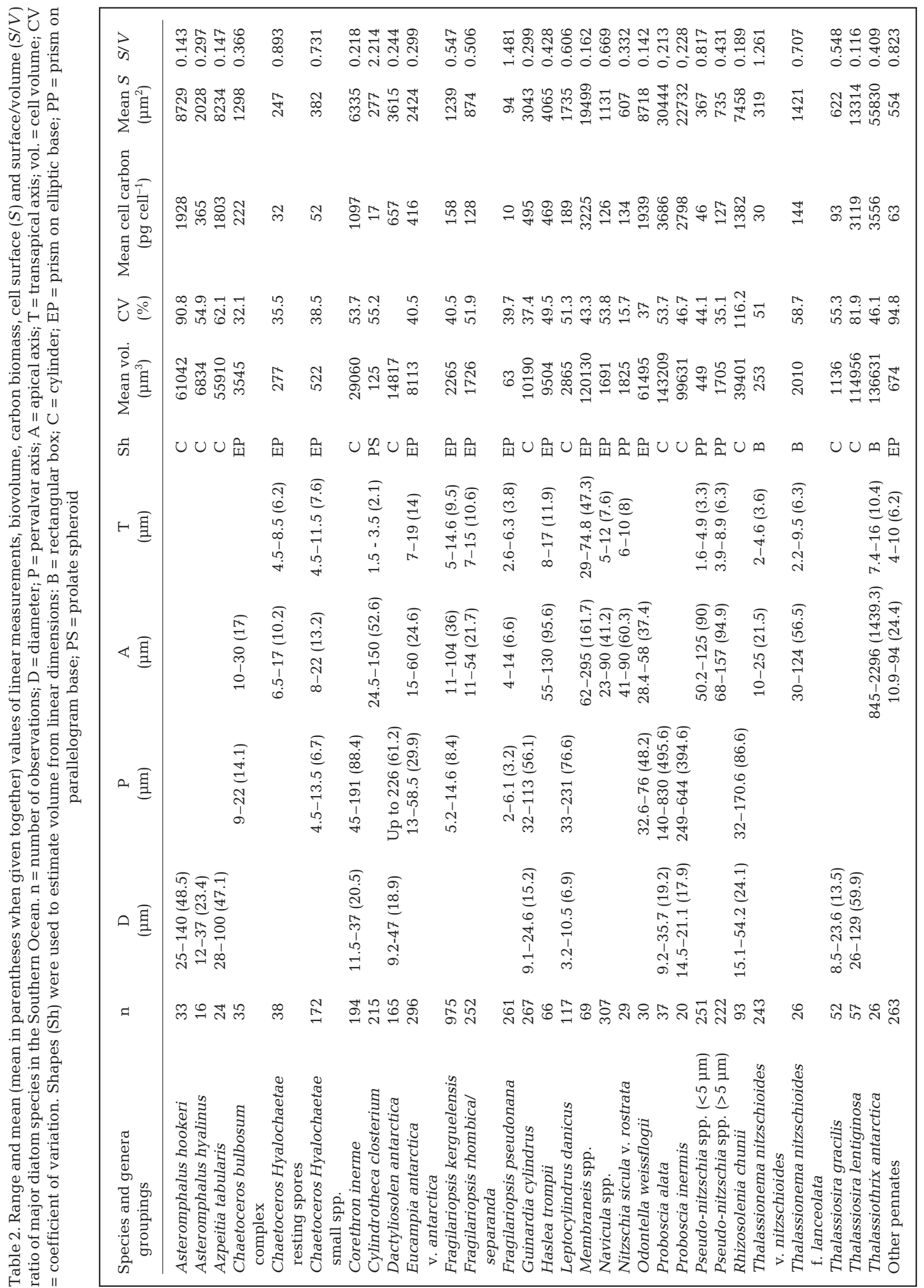


Table 3. Fragilariopsis kerguelensis and F. pseudonana. Average linear dimensions and determination of the pervalvar to transapical ratio (P:T) in pennate diatoms based on multiple measurements from $F$. kerguelensis and F. pseudonana. $\mathrm{n}=$ number of observations

\begin{tabular}{|lcccc|}
\hline Species & $\begin{array}{c}\text { Transapical } \\
\text { axis }(\mu \mathrm{m})\end{array}$ & $\begin{array}{c}\text { Pervalvar } \\
\text { axis }(\mu \mathrm{m})\end{array}$ & $\mathrm{P}: \mathrm{T}$ & $\mathrm{n}$ \\
\hline F. kerguelensis & 9.91 & 8.75 & 0.88 & 128 \\
F. pseudonana & 3.66 & 3.29 & 0.90 & 50 \\
\hline
\end{tabular}

Asteromphalus hookeri, 'other pennates' and Rhizosolenia chunii, for which \% CVs were 81.9, 90.8, 94.8 and $116.2 \%$, respectively (Table 2 ).

\section{DISCUSSION}

\section{Linear measurements}

We compared our linear measurements with data from the most recent and comprehensive documentation of cell dimensions found in Hasle \& Syverstsen (1997) (Table 4). Our data were in good general agreement with these data and include new axis measurements for several genera or taxa groupings, specifically Chaetoceros, Eucampia, Leptocylindrus, Membraneis, Odontella and Proboscia. Nevertheless, some species showed smaller or larger variations in sizes than the data summarised in the literature. The most notable differences being as follows: (1) The diameter of Asteromphalus hookeri ranged between 25 and $140 \mu \mathrm{m}$ in our study and is reported as much smaller (25 to $60 \mu \mathrm{m})$; however, only $10 \%$ of the diameters measured in our study exceeded $60 \mu \mathrm{m}$. (2) Corethron inerme has a minimal diameter measurement of $11.5 \mu \mathrm{m}$, whereas the minimal value previously cited is $30 \mu \mathrm{m}$. (3) Eucampia antarctica v. antarctica cells have small apical axis values, with $10 \%$ being less than the cited minimum of $18 \mu \mathrm{m}$. (4) Of the Fragilariopsis kerguelensis specimens, 1.5\% have an apical axis greater than the maximum cited value of $76 \mu \mathrm{m}$; the maximum value observed in this study being $104 \mu \mathrm{m}$. Recent data from initial cell formation in $F$. kerguelensis indicate a greatest apical axis length of between 76 and $90 \mu \mathrm{m}$ for this species (Assmy et al. 2006). (5) Of Membraneis spp., $82 \%$ have an apical axis greater than the maximum cited value of $125 \mu \mathrm{m}$. The maximum value observed in this study being $295 \mu \mathrm{m}$. (6) Of the Rhizosolenia chunii specimens, 38\% have maximal diameters $>28 \mu \mathrm{m}$ (largest observed $54.2 \mu \mathrm{m})$ while $26 \%$ have a maximal pervalvar axis $>94 \mu \mathrm{m}$ (longest observed $170.6 \mu \mathrm{m}$ ), compared with data in Hasle \& Syvertsen (1997). (7) Of Thalassionema nitzschioides v. nitzschioides, $72 \%$ have an apical axis $>10 \mu \mathrm{m}$ compared with measurements listed in Moreno-Ruiz \& Licea (1995). (8) All Thalassiothrix antarctica specimens measured in this study have a transapical axis wider than data reported in the literature.

Overall, basic combined linear measurements for each species did not indicate large departures from previous summed observations. Variations may be regional and also heavily influenced by the cell cycle phase evident during bloom decline at our repeat sampling stations.

\section{Carbon calculations}

We compared our carbon biomass values calculated according to the Eppley et al. (1970) equation with results obtained with $\mathrm{C}$ : Vol regressions from the MDL equations; the results differed from $0.4 \%$ (Odontella weissflogii) to $24 \%$ (Asteromphalus hyalinus) (Table 5). These new data predicted 16 to $24 \%$ less C for diatoms with biovolumes between 7000 and $14800 \mu^{3}$ (5 diatoms species in our study: Dactyliosolen antarctica, Eucampia antarctica, Haslea trompii, Guanardia cylindrus, Asteromphalus hyalinus) and also the minute diatom Fragilariopsis pseudonana, and predicted 7.5 to $10.4 \%$ more C for 4 large diatoms (>100 $000 \mathrm{\mu m}^{3}$ : Membraneis spp., Proboscia alata, Thalassiosira lentiginosa, Thalassiothrix antarctica). Differences were minor for the other species.

Although Menden-Deuer \& Lessard (2000) differentiated diatoms on the basis of large biovolumes $>3000{\mu \mathrm{m}^{3}}^{3}$, this division was defined from comparison with other non-diatom phytoplankton groups where biomass could not be extracted from a single all-encompassing equation. The larger biovolume diatom cells were considered less dense and thus subjected to an alternative equation that decreased their $\mathrm{C}$ content. In Fig. 2 we show that a difference in the $\mathrm{C}$ biomass estimates is strikingly obtained when a species' volume is greater than $65000 \mu^{3}$ and not at $3000 \mu^{3}$ as presented by Menden-Deuer \& Lessard (2000).

The species used to date in determining such $\mathrm{C}$ biomass equations rarely represent those observed in our samples (i.e. Chaetoceros spp.). In all the studies mentioned thus far (see 'Materials and methods') the largest species identified $\left(>65000 \mu^{3}\right)$ fall into the taxa Coscinodiscus spp. and C. Concinnus, Ditylum brightwellii and Rhizosolenia setigera, whereas we encounter large biovolume species in the genera Membraneis, Proboscia, Thalassiosira and Thalassiothrix (Table 2).

Due to the need for additional comparative work and integration of Southern Ocean species in such equations and the additional fact that we wished to compare 


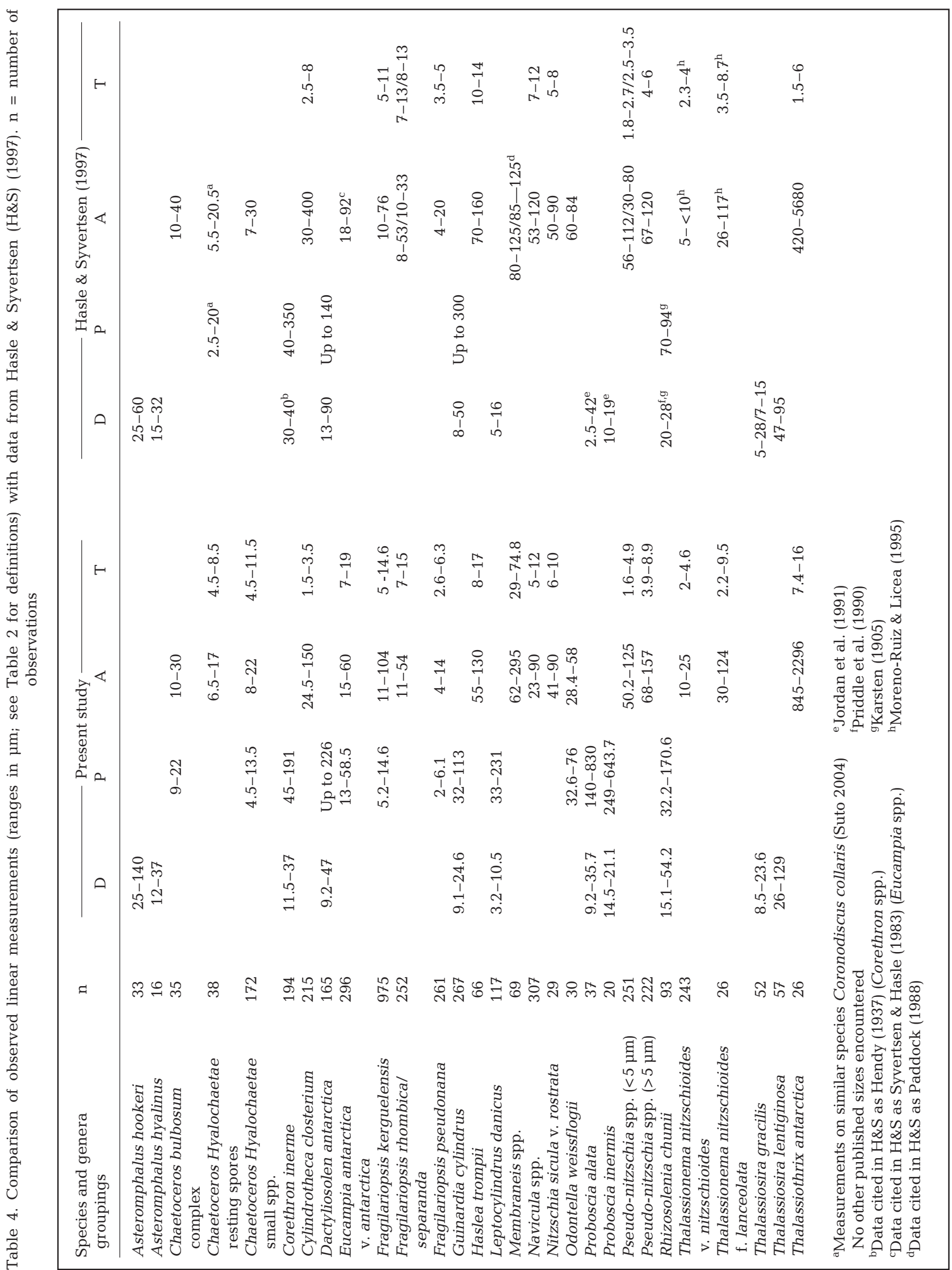


Table 5. Biomass estimation comparison between the corrected equation of Eppley et al. (1970) (corrected in Smayda 1978) and the equations of Menden-Deuer \& Lessard (2000) (MDL). Percent variation is the difference of Eppley-MDL over the corrected Eppley et al. (1970) equation

\begin{tabular}{|c|c|c|c|c|c|}
\hline Species and genera groupings & $\begin{array}{l}\text { Biovolume } \\
\qquad\left(\mu \mathrm{m}^{3}\right)\end{array}$ & $\begin{array}{c}\text { Eppley } \\
\left(\text { pg C cell }{ }^{-1}\right)\end{array}$ & $\begin{array}{c}\text { MDL } \\
\text { diatom }<3000 \mu \mathrm{m}^{3} \\
\left(\mathrm{pg} \mathrm{C} \mathrm{cell}{ }^{-1}\right)\end{array}$ & $\begin{array}{c}\text { MDL } \\
\text { diatom }>3000 \mu \mathrm{m}^{3} \\
\left(\mathrm{pg} \mathrm{C} \mathrm{cell}{ }^{-1}\right)\end{array}$ & $\begin{array}{c}\text { Variation } \\
(\%)\end{array}$ \\
\hline Asteromphalus hookeri & 61042 & 1928 & & 1919 & 0.4 \\
\hline Asteromphalus hyalinus & 6834 & 365 & & 279 & 23.6 \\
\hline Azpeitia tabularis & 55910 & 1803 & & 1776 & 1.5 \\
\hline Chaetoceros bulbosum complex & 345 & 38 & 33 & & 12.8 \\
\hline Chaetoceros Hyalochaetae resting spores & 277 & 32 & 28 & & 13.8 \\
\hline Chaetoceros Hyalochaetae small spp. & 522 & 52 & 46 & & 11.0 \\
\hline Corethron inerme & 29060 & 1097 & & 998 & 9.0 \\
\hline Cylindrotheca closterium & 125 & 17 & 14 & & 17.2 \\
\hline Dactyliosolen antarctica & 14817 & 657 & & 551 & 16.1 \\
\hline Eucampia antarctica & 8113 & 416 & & 324 & 22.0 \\
\hline Fragilariopsis kerguelensis & 2265 & 158 & 151 & & 4.0 \\
\hline Fragilariopsis rhombica/separanda & 1726 & 128 & 121 & & 5.4 \\
\hline Fragilariopsis pseudonana & 63 & 10 & 8 & & 20.1 \\
\hline Guinardia cylindrus & 10190 & 495 & & 396 & 19.8 \\
\hline Haslea trompii & 9504 & 469 & & 373 & 20.5 \\
\hline Leptocylindrus danicus & 2865 & 189 & 183 & & 2.9 \\
\hline Membraneis spp. & 120130 & 3225 & & 3485 & -8.1 \\
\hline Navicula spp. & 1691 & 126 & 119 & & 5.5 \\
\hline Nitzschia sicula v. rostrata & 1825 & 134 & 127 & & 5.1 \\
\hline Odontella weissflogii & 61495 & 1939 & & 1932 & 0.4 \\
\hline Proboscia alata & 143209 & 3686 & & 4068 & -10.4 \\
\hline Proboscia inermis & 99631 & 2798 & & 2955 & -5.6 \\
\hline Pseudo-nitzschia spp. $(<5 \mu \mathrm{m})$ & 449 & 46 & 41 & & 11.6 \\
\hline Pseudo-nitzschia spp. (>5 $\mu \mathrm{m})$ & 1705 & 127 & 120 & & 5.4 \\
\hline Rhizosolenia chunii & 39401 & 1382 & & 1305 & 5.6 \\
\hline Thalassionema nitzschioides v. nitzschioides & 253 & 30 & 26 & & 14.2 \\
\hline Thalassionema nitzschioides f. lanceolata & 2010 & 144 & 137 & & 4.6 \\
\hline Thalassiosira gracilis & 1136 & 93 & 86 & & 7.4 \\
\hline Thalassiosira lentiginosa & 114956 & 3119 & & 3352 & -7.5 \\
\hline Thalassiothrix antarctica & 136631 & 3556 & & 3903 & -9.7 \\
\hline Other pennates & 674 & 63 & 57 & & 9.8 \\
\hline
\end{tabular}

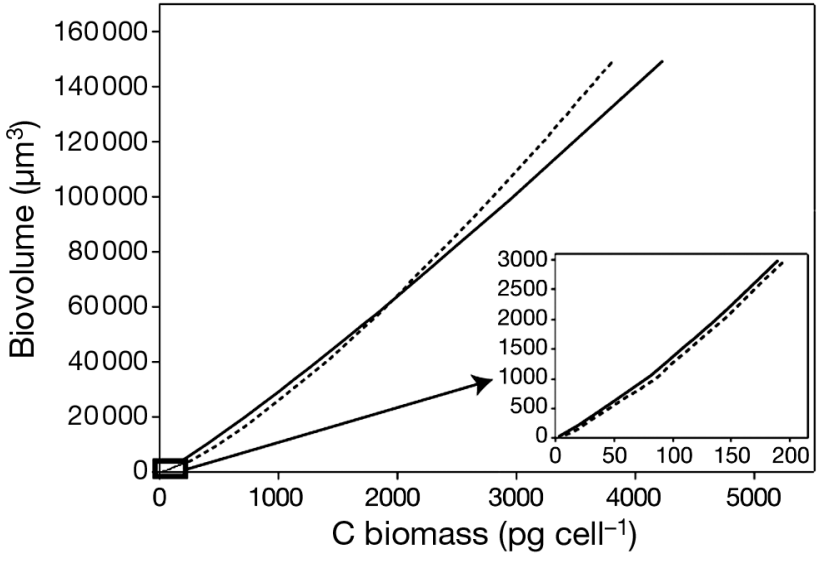

Fig. 2. Plot of diatom biomass estimates using the corrected equation of Eppley et al. (1970) (corrected in Smayda 1978) (dashed line) and the 2 equations of Menden-Deuer \& Lessard (2000) (MDL; solid line). Biomass estimates are derived from arbitrary biovolumes between 0 and $150000 \mu^{3}$, covering the range of biovolumes encountered in our study. The inset specifically reveals estimates of biovolumes $\leq 3000{\mu \mathrm{m}^{3}}^{3}$, which separates the use of $2 \mathrm{MDL}$ equations our results with those currently published from the Southern Ocean (i.e. Moro et al. 2000 and Kang et al. 2001) we decided to continue use of the corrected Eppley et al. (1970) equation to predict C content in this study. It would seem appropriate that additional modification of current C:Vol equations are required to capture Southern Ocean diatom variability. We did not undertake this extension in this study.

\section{Cell volume, carbon content and surface to volume ratios}

Biovolume and carbon biomass results were compared principally against the sea ice or ice-edge community studies of Moro et al. (2000) and Kang et al. (2001) (Table 6). Moro et al. (2000) present biovolume measurements from Wood Bay, Ross Sea, whereas Kang et al. (2001) represent research around the northern tip of the Antarctic Peninsula in the Weddell Sea. 
Table 6. Species-specific comparison of mean cell biovolume and mean cell carbon biomass with results from Moro et al. (2000) and Kang et al. (2001). Pennate results from Kang et al. (2001) recalculated with equivalent geometric shapes of this study in parentheses. Vol. = cell volume; Shapes $(\mathrm{Sh})$ were used to estimate volume from linear dimensions: $\mathrm{C}=\mathrm{cylinder} ; \mathrm{EP}=$ prism on elliptic base; $\mathrm{PP}=$ prism on parallelogram base; $\mathrm{PS}=$ prolate spheroid; $\mathrm{B}=$ rectangular box

\begin{tabular}{|c|c|c|c|c|c|c|c|}
\hline \multirow{2}{*}{$\begin{array}{l}\text { Species and genera } \\
\text { groupings }\end{array}$} & \multicolumn{3}{|c|}{ _ Present study } & \multirow{2}{*}{$\begin{array}{c}\text { Moro et al. (2000) } \\
\text { Vol. } \\
\left(\mu \mathrm{m}^{3}\right)\end{array}$} & \multirow{2}{*}{$\overline{\mathrm{Sh}}^{\mathrm{I}}$} & \multicolumn{2}{|c|}{ Kang et al. (2001) } \\
\hline & $\mathrm{Sh}$ & $\begin{array}{l}\text { Vol. } \\
\left(\mu \mathrm{m}^{3}\right)\end{array}$ & $\begin{array}{l}\text { Cell carbon } \\
\left(\mathrm{pg} \mathrm{cell}^{-1}\right)\end{array}$ & & & $\begin{array}{l}\text { Vol. } \\
\left(\mu \mathrm{m}^{3}\right)\end{array}$ & $\begin{array}{l}\text { Cell carbon } \\
\left(\mathrm{pg} \mathrm{cell}^{-1}\right)\end{array}$ \\
\hline Azpeitia tabularis & $\mathrm{C}$ & 55910 & 1803 & & $\mathrm{C}$ & 13451 & 611 \\
\hline Chaetoceros bulbosum complex & EP & 3545 & 222 & 4568 & & & \\
\hline $\begin{array}{l}\text { Chaetoceros Hyalochaetae } \\
\text { resting spores }\end{array}$ & EP & 246 & 29 & & EP (B) & 118 & 17 \\
\hline $\begin{array}{l}\text { Chaetoceros Hyalochaetae } \\
\text { small spp. }\end{array}$ & EP & 522 & 52 & & EP (B) & 257 & 30 \\
\hline Corethron inerme $\mathrm{a}^{\mathrm{a}}$ & $\mathrm{C}$ & 29060 & 1097 & 68427 & $\mathrm{C}$ & 41720 & 1444 \\
\hline Cylindrotheca closterium & PS & 125 & 17 & 663 & PS & 268 & 31 \\
\hline Eucampia antarctica v. antarctica & EP & 8113 & 416 & 111182 & EP (B) & 50377 & 1666 \\
\hline Fragilariopsis kerguelensis & EP & 2265 & 158 & & EP (B) & 1483 & 114 \\
\hline Fragilariopsis rhombica/separanda & EP & 1726 & 128 & $2364 / 1942$ & EP (B) & $827 / 2356$ & $73 / 162$ \\
\hline Fragilariopsis pseudonana & EP & 63 & 10 & & EP (B) & 177 & 23 \\
\hline Guanardia cylindrus & $\mathrm{C}$ & 10190 & 495 & 1346 & & & \\
\hline Haslea trompii & EP & 9504 & 469 & & EP (B) & 8207 & 420 \\
\hline Navicula spp. ${ }^{\mathrm{b}}$ & EP & 1691 & 126 & 5715 & $\mathrm{EP}(\mathrm{B})$ & 3727 & 230 \\
\hline Odontella weissflogii ${ }^{\mathrm{C}}$ & EP & 61495 & 1939 & 190806 & $\mathrm{EP}(\mathrm{B})$ & 88008 & 2546 \\
\hline Proboscia alata & $\mathrm{C}$ & 143209 & 3686 & 10911 & $\mathrm{C}$ & 40886 & 1422 \\
\hline Proboscia inermis & $\mathrm{C}$ & 99631 & 2798 & & $\mathrm{C}$ & 29824 & 1119 \\
\hline Pseudo-nitzschia spp. $(<5 \mu \mathrm{m})^{\mathrm{d}}$ & PP & 449 & 46 & 132 & PP (PS) & 510 & 51 \\
\hline Pseudo-nitzschia spp. $(>5 \mu \mathrm{m})^{\mathrm{e}}$ & PP & 1705 & 127 & & PP (PS) & 922 & 77 \\
\hline Thalassiosira gracilis & $\mathrm{C}$ & 1136 & 93 & & $\mathrm{C}$ & 2633 & 177 \\
\hline Thalassiosira lentiginosa & $\mathrm{C}$ & 114956 & 3119 & & $\mathrm{C}$ & 88856 & 2564 \\
\hline \multicolumn{8}{|c|}{ 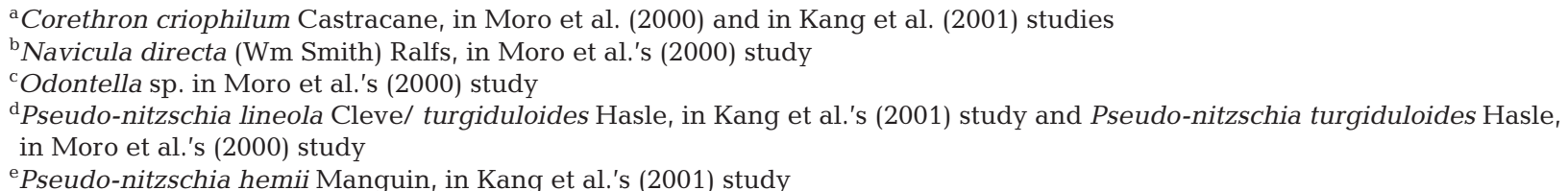 } \\
\hline
\end{tabular}

Differences for 10 species between the 3 studies reveal cell biovolumes that vary considerably. Guinardia cylindrus, Proboscia alata and Pseudo-nitzschia spp. $(<5 \mu \mathrm{m})$ all reveal the smallest biovolumes in the Ross Sea study, while the remainder of the common species have the largest biovolumes of any of the 3 studies. We believe that sea-surface temperatures play an important role in the environmental preference and thus size and frustule structure of a species as is often reported in the literature (eg. Villareal \& Fryxell 1983, Smith et al. 1994, Suzuki \& Takahashi 1995, Montagnes \& Franklin 2001, Atkinson et al. 2003). Other environment linked variables such as light and nutrient supply cannot be excluded either (e.g. Fiala \& Oriol 1990, Stapleford \& Smith 1996, Stramski et al. 2002); however, explicit Southern Ocean diatom ecology or life cycle research is depauperate in the literature, resulting in generalised hypotheses on any cause and response for any single species.

Alternatively, differences in biovolume measurements can be attributed to valid taxonomic differences within a species, such as forms or varieties. This explanation can be applied to the case of Eucampia antarctica biovolume measurements in Table 6, where the Moro et al. (2000) and Kang et al. (2001) studies show E. antarctica biovolumes 13.7 and 6.2 times larger, respectively, to the specimens we report around Kerguelen. It is evident that the Ross and Weddell Sea forms encountered in the comparative papers represent the flat ribbon chained E. antarctica var. recta, and in our survey, the spiralling chained form of E. antarctica var. antarctica (form descriptions in Fryxell \& Prasad 1990). We cannot discount the fact that species identified as Corethron criophilum by the previous studies (see footnotes in Tables 3 \& 4) and Corethron inerme in the present study account for the differences observed in biovolume and biomass estimates, although it is highly likely, and thus rigorous taxonomic treatment employing the taxonomic differences reported in Crawford et al. (1998) will assist in future definitions of species contributions to the carbon cycle. 
An important point to consider in comparing biovolumes is the use of shape equations to determine these values. The Kang et al. (2001) study did not correct for vacuole size, but employed alternative pennate-shape equations (i.e. rectangular and prolate spheroid) to resolve their biovolume values, against the Hillebrand et al. (1999) standardized genera equations we apply here. We recalculate their specific volumes and subsequent biomass contributions in Table 6 in order to make comparison possible between our studies. The comparison of biovolume and biomass estimates of individual species in our study against those in more southerly waters evoke a biogeographic delineation dependent on a species generally reported habitat, such that greater values of either estimate for that species follow suite. For example Thalassiosira lentiginosa, Azpeitia tabularis, Fragilariopsis kerguelensis and Pseudo-nitzschia (>5 $\mu \mathrm{m}$ category), which have larger biovolume and biomass estimates in our study, are known to thrive in openocean regions (Hasle \& Syvertsen 1997, Crosta et al. 2005). In contrast, Cylindrotheca closterium, Fragilariopsis pseudonana and Thalassiosira gracilis are reported with larger biovolume and biomass estimates in the marginal sea-ice to ice-affected studies, where they are dominantly observed (Kang \& Fryxell 1993, Hasle \& Syvertsen 1997, Garibotti et al. 2003). The implication with this comparison of biovolumes is to highlight the need for a standardized species-specific approach in future research, which we propose rests with the genus determined equations of Hillebrand et al. (1999).

Cell volume estimates have also been subjected to an arbitrary definition, discriminating small and large diatoms by a delimiting cell volume of $1000 \mu^{3}$ (Snoeijs et al. 2002). Employing this definition to our Southern Ocean species indicates that 7 taxa (Chaetoceros Hyalochaetae species and resting spores, Cylindrotheca closterium, Fragilariopsis pseudonana, Pseudo-nitzschia ( $<5 \mu \mathrm{m}$ category), Thalassionema nitzschioides v. nitzschioides, and 'other pennates') could be considered as small diatoms $\left(<1000 \mu^{3}=<85 \mathrm{pg} \mathrm{C}^{3}\right.$ cell $\left.^{-1}\right)$, whereas the remaining 24 taxa could be defined as large diatoms (Table 2). We believe this arbitrary classification can be divided into a further division, which we identify as intermediate between small and large diatoms. We define intermediate diatoms as those with a cell volume between 1000 and $10000 \mu^{3}$ (equivalent to $85>x>488 \mathrm{pg} \mathrm{C}$ $\mathrm{cell}^{-1}$ ), thus delimiting large diatoms as those with volumes greater than $10000 \mu^{3}$. Under this definition the 24 remaining taxa can be divided into 12 intermediate sized diatoms and 12 large diatom species (Table 7). This size defining application could be employed in future modelling studies or carbon budget calculations that wish to differentiate carbon contributions from large, intermediate and small diatoms in terms of biomass rather than by bulk size-fractionated assessments based on filter mesh sizes and generalised definitions of pico- $(0.2$ to $2 \mu \mathrm{m})$, nano- (2 to $20 \mu \mathrm{m})$ and

Table 7. KEOPS species and taxa groupings divided into small, intermediate and large diatom contributors based on volume definitions of Snoeijs et al. (2002) and this work in comparison with derived $S / V$ ratios and mean cellular carbon contributions

\begin{tabular}{|c|c|c|c|}
\hline $\begin{array}{l}\text { Diatom size category } \\
\text { Species and genera groupings }\end{array}$ & $\begin{array}{l}\text { Mean cell } \\
\text { vol. }\left(\mu \mathrm{m}^{3}\right)\end{array}$ & $S / V$ & $\begin{array}{l}\text { Mean carbon } \\
\left(\operatorname{pg~C~cell~}{ }^{-1}\right)\end{array}$ \\
\hline \multicolumn{4}{|l|}{ Small $\left(<1000 \mu^{3}\right)^{3}$} \\
\hline Fragilariopsis pseudonana & 63 & 1.481 & 10 \\
\hline Cylindrotheca closterium & 125 & 2.214 & 17 \\
\hline Thalassionema nitzschioides v. nitzschioides & $s \quad 253$ & 1.261 & 30 \\
\hline $\begin{array}{l}\text { Chaetoceros Hyalochaetae resting } \\
\text { spores }\end{array}$ & 277 & 0.893 & 32 \\
\hline Pseudo-nitzschia spp. $(<5 \mu \mathrm{m})$ & 449 & 0.817 & 46 \\
\hline Chaetoceros Hyalochaetae small spp. & 522 & 0.731 & 52 \\
\hline Other pennates & 674 & 0.823 & 63 \\
\hline \multicolumn{4}{|l|}{ Intermediate $\left(>1000,<10000 \mathrm{\mu m}^{3}\right)$} \\
\hline Thalassiosira gracilis & 1136 & 0.548 & 93 \\
\hline Navicula spp. & 1691 & 0.669 & 126 \\
\hline Pseudo-nitzschia spp. (>5 $\mu \mathrm{m})$ & 1705 & 0.431 & 127 \\
\hline Fragilariopsis rhombica/separanda & 1726 & 0.506 & 128 \\
\hline Nitzschia sicula v. rostrata & 1825 & 0.332 & 134 \\
\hline $\begin{array}{l}\text { Thalassionema nitzschioides } \mathrm{f} . \\
\text { lanceolata }\end{array}$ & 2010 & 0.707 & 144 \\
\hline Fragilariopsis kerguelensis & 2265 & 0.547 & 158 \\
\hline Leptocylindrus danicus & 2865 & 0.606 & 189 \\
\hline Chaetoceros bulbosum complex & 3545 & 0.366 & 222 \\
\hline Asteromphalus hyalinus & 6834 & 0.297 & 365 \\
\hline Eucampia antarctica v. antarctica & 8113 & 0.299 & 416 \\
\hline Haslea trompii & 9504 & 0.428 & 469 \\
\hline \multicolumn{4}{|l|}{ Large $\left(>10000 \mu^{3}\right)$} \\
\hline Guinardia cylindrus & 10190 & 0.299 & 495 \\
\hline Dactyliosolen antarctica & 14817 & 0.244 & $\mathrm{n} / \mathrm{a}$ \\
\hline Corethron inerme & 29060 & 0.218 & 1097 \\
\hline Rhizosolenia chunii & 39401 & 0.189 & 1382 \\
\hline Azpeitia tabularis & 55910 & 0.147 & 1803 \\
\hline Asteromphalus hookeri & 61042 & 0.143 & 1928 \\
\hline Odontella weissflogii & 61495 & 0.142 & 1939 \\
\hline Proboscia inermis & 99631 & 0.228 & 2798 \\
\hline Thalassiosira lentiginosa & 114956 & 0.116 & 3119 \\
\hline Membraneis spp. & 120130 & 0.162 & 3225 \\
\hline Thalassiothrix antarctica & 136631 & 0.409 & 3556 \\
\hline Proboscia alata & 143209 & 0.213 & 3686 \\
\hline
\end{tabular}


microplankton (20 to $200 \mu \mathrm{m}$ ) contributions that do not resemble the diversity of shapes found in diatoms and thus respective biomass contributions.

Although mean cell volumes are used here to indicate a mean species value, the variation, as illustrated by the \%CV values, is equally important in assessing the variation within the population. In this case, the small \%CV values associated with a given mean volume provide a measure of size dispersion in the given volume and subsequent biomass estimates. In our study the majority of \%CV range between 32 and $62 \%$. We cannot say at this time whether this represents a normal species variability range outside of the Menden-Deuer et al. (2001) study, since there are no other studies in this fashion. In our study, measured cells are derived from 2 different stations, within and exterior to the bloom, taken at 2 different times; therefore, cells of one species could differ in size dependent on various life cycle stages observed (e.g. vegetative stages observed at the first visit compared to resting stages as the bloom ended, or large cells at one site compared with small cells at another site). So it is not surprising that \% CV tend to be mid-large in value when size is variable over time and space. One distinction we are able to decipher with one of the large $\% \mathrm{CV}$ values (Rhizosolenia chunii, $116.2 \%$ ) is that sizes are smaller in samples from Stn A3 (bloom conditions) compared with samples from Stn C11 (high nutrient low chlorophyll, HNLC). Separated by station, Rhizosolenia chunii mean biovolume is $14734 \mu^{3}$ (\% CV $=27.2)$ at $\mathrm{Stn} \mathrm{A} 3$ and $106436 \mu^{3}(\% \mathrm{CV}=24.9)$ in samples from Stn C11 (Fig. 3).

It would appear that the combination of the 2 stations and differing species populations may result in \%CV values $>60 \%$ (Table 2). However, the same did not hold true for Thalassiosira lentiginosa with an $81 \% \mathrm{CV}$, as Stn A3 samples with a smaller biovolume of $34382 \mathrm{\mu m}^{3}$ compared with the biovolume of $132275 \mu^{3}$ at Stn C11 both show large \% CV values (43.9 and $73.3 \%$, respectively), suggesting that the populations at both sites have heterogeneous size ranges.

In theory, diatoms can adapt to low nutrient concentrations by reducing their size through successive vegetative division; small cells have greater $S / V$ ratio, which increases the exchanges of solutes across the cell surface (Morel et al. 1991). For both Rhizosolenia chunii and Thalassiosira lentiginosa this hypothesis may support our observations of declining bloom conditions (Blain et al. 2007) at Stn A3 with the smaller biovolume and larger $S / V$ estimates of these species than estimated for the population in the HNLC region at Stn C11 ( $R$. chunii $S / V=0.262$ at Stn A3 and 0.136 at Stn C11; T. lentiginosa $S / V=0.173$ at Stn A3 and 0.111 at Stn C11). However, it is most likely that size diminution of $R$. chunii and T. lentiginosa at Stn A3 is a result of faster vegetative division in the previously nutrient rich Stn A3 waters compared to the nutrient-limited populations at Stn C11.

$S / V$ ratios for 4 species - Cylindrotheca closterium (2.68), Leptocylindrus danicus (0.67), Proboscia alata (0.62) and Thalassionema nitzschioides (1.03) - were reported from the Baltic Sea by Snoeijs et al. (2002) and form the basis of possible comparisons with our study. In all cases, the $S / V$ ratios are strikingly similar, with the exception of the value for $P$. alata for which the $S / V$ ratio is much smaller in our South Ocean species (0.213). This discrepancy could be related to several factors, not the least of which life cycle stage and actual taxonomic differences are likely candidates.
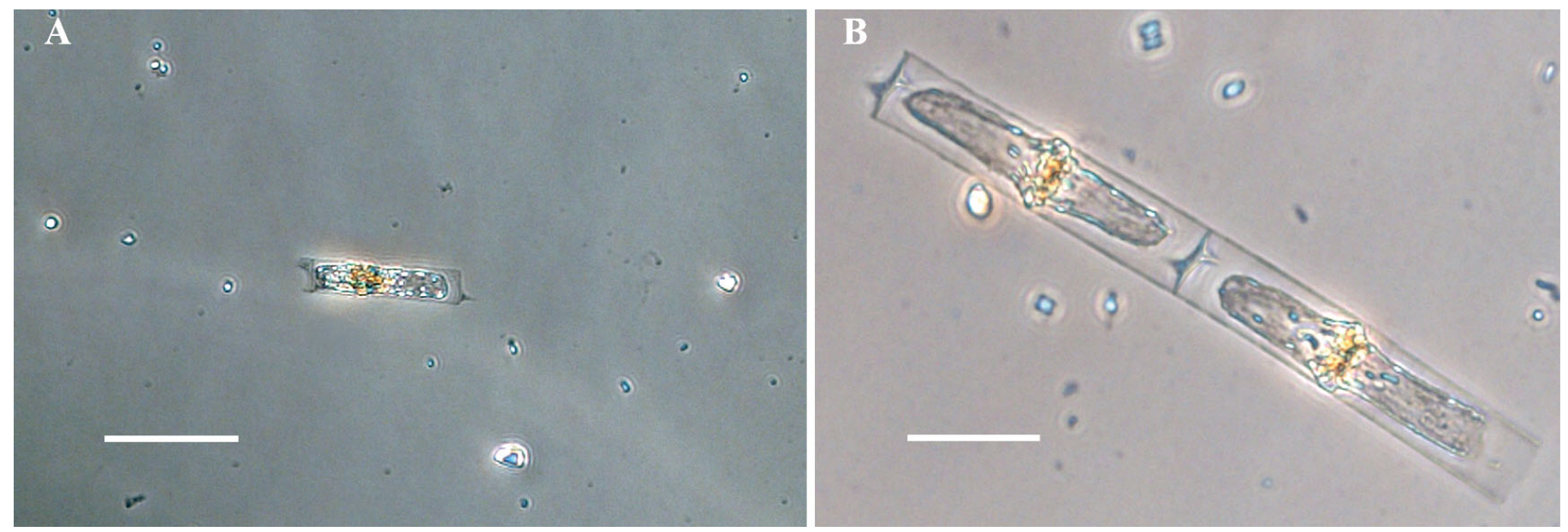

Fig. 3. Rhizosolenia chunii at (A) Stn A3 within the plateau bloom region and (B) Stn C11 out of bloom region, over the Kerguelen Plateau in the Southern Ocean. Scale bars $=50 \mu \mathrm{m}$ 
A theory driven by Smetacek and colleagues in recent years (Verity \& Smetacek 1996, Smetacek et al. 2002, 2004, Hamm et al. 2003) in assessing phytoplankton biomass success has resulted in a hypothesis of mortality adaptation as an explanation for biomass accumulation of larger phytoplankton in the openocean environment; via defensive changes to the frustule such as increased size/length, highly silicified cells and defence mechanisms such as spines, protrusions and barbs. This mortality adaptation is considered costly to faster division, improved nutrient uptake and thinner frustules, which would ordinarily allow greater biomass accumulation in a high-nutrient, lowpredation environment. The biomass accumulation of larger or heavily protected species in a community also suggests that limiting nutrient sources (such as iron or silica) are realised from the regeneration pool of the smaller taxa (Smetacek et al. 2002). In general, high $S / V$ ratios are associated with small cell size and in this sense would represent uptake specialist diatoms; conversely, small $S$ / $V$ ratios linked to larger cells represent predation defence specialists. The majority of our species reveal small $S / V$ ratios (i.e. $<0.3$ ), which would suggest that the Kerguelen community is predation defensive (Tables 2 \& 7 ).

Our categorised diatom size contributors derived from uncorrected cell volumes against a species $S / V$ ratio indicate that small diatoms in our samples have $S / V$ ratios of $>0.7$, intermediate diatoms have an $S / V$ ratio range between 0.2 and 0.7 , whereas large diatoms have an $S / V$ ratio of $<0.2$. The sole exception to this relation is that observed with Thalassiothrix antarctica, for which biovolume values suggest that the species can be considered a large cell whereas the calculated $S / V$ ratio is 0.4 . We assume this discrepancy is related to sample methodology, where we were more likely to have encountered smaller specimens of T. antarctica in our CTD sampling of the water column.

\section{CONCLUSIONS}

Our study is the first to describe the carbon content of major diatom species in the open ocean region of the Southern Ocean. These values are determined from multiple linear measurements of specimens in 2 neighbouring, yet biogeochemically contrasting, regions over a month long period at the end of the summer bloom period southeast of Kerguelen Island. Our linear measurements show minimal discrepancies from measurements previously encountered and summarised in the literature. We expect that some of the observed variation is derived from the vegetative phase of reproduction observed as a result of the bloom conditions. We believe that this variation in size of a species popu- lation is seen in the values provided by \%CV. However, we are relatively uncertain, given that this represents the first time such measurements have been given for these species, whether such values indicate a normal range of size dispersion in bloom affected cells, variation in biogeochemically differentiated populations of the same species or other unidentified factors.

Biovolume and subsequent biomass measurements varied from $63 \mathrm{~mm}^{3}$ and $10 \mathrm{pg} \mathrm{C}$ cell $^{-1}$ in Fragilariopsis

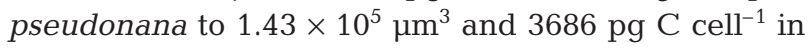
Proboscia alata. We suggest that future biomass determinations follow the Hillebrand et al. (1999) genusspecific geometric equations to enable comparison between studies. The use of a C:Vol equation, as represented either by the corrected Eppley et al. (1970) or biovolume differentiated MDL equations, is not an easy choice given that neither takes into account taxa that are generally dominant in the Southern Ocean to determine their equations, particularly those with larger biovolume estimates. We choose out of comparison convenience to use the corrected Eppley et al. (1970) equation, noting that in comparison to the MDL equations only when biovolume was exceptionally large did major discrepancies between estimates occur. Obviously, the next step would be to define new modified MDL type equations that take into account Southern Ocean diatom size variations along with new studies on carbon contents of the same taxa.

The need to assess vacuole size in diatoms is a difficult and time intensive task, most unlikely to be assessed for sometime. This measure remains the largest uncertainty in our study and we accept that our biomass estimates lack this correction as should all future studies. We employed and extended the biovolume definition of Snoeijs et al. (2002) to designate cell size and subsequent carbon contributor status to the diatoms encountered in our samples. This simple definition presents a more useful description of a diatom community, with respect to any one of the 3 biovolume-derived measurements in Table 7 , than presented to date by generalised size definitions of phytoplankton communities (pico-, nano- and microplankton). We expect improvements on the definitions and Table 7 with time and additional significant studies of phytoplankton in the ocean. The definition of mean biomass contribution here with abundance data (L. K. Armand et al. unpubl.) will lead to a more meaningful assessment of the carbon contribution of phytoplankton within the oceanic carbon cycle as has been initiated in the KEOPS program.

Acknowledgements. We thank the Captain and crew of the RV 'Marion Dufresne II' and scientific participants of the KEOPS mission (No. 145). Drs. M. Baklouti, S. Blain, R. Jordan, I. Suko and J. Rines are thanked for their discussions on 
various aspects of the paper. The thoughtful commentary of our 3 anonymous reviewers improved the manuscript. This work was supported by the Centre National de la Recherche Scientifique (CNRS), Institut National des Sciences de L'Univers (INSU) and l'Institut Paul Emile Victor (IPEV). L.A. is funded by a European Union FTP6 Marie Curie International Incoming Fellowship.

\section{LITERATURE CITED}

Agustí S, Duarte CM (2000) Experimental induction of a large phytoplankton bloom in Antarctic coastal waters. Mar Ecol Prog Ser 206:73-85

Ahn IY, Chung H, Kang JS, Kang SH (1997) Diatom composition and biomass variability in nearshore waters of Maxwell Bay, Antarctica, during the 1992-1993 austral summer. Polar Biol 17:123-130

Anonymous (1974) A review of methods used for quantitative phytoplankton studies. Final Report of SCOR Working Group 33. UNESCO Tech Pap Mar Sci18, UNESCO, Paris

Assmy P, Henjes J, Smetacek V, Montresor M (2006) Auxospore formation by the silica-sinking, oceanic diatom Fragilariopsis kerguelensis (Bacillariophyceae). J Phycol 42:1002-1006

Atkinson D, Ciotti BJ, Montagnes DJS (2003) Protists decrease in size linearly with temperature: ca. $2.5 \%{ }^{\circ} \mathrm{C}^{-1}$. Proc R Soc Lond B 270:2605-2611

Bathmann UV, Scharek R, Klaas C, Dubischar CD, Smetacek V (1997) Spring development of phytoplankton biomass and commposition in major water masses of the Atlantic sector of the Southern Ocean. Deep-Sea Res II 44(1-2): 51-67

Blain S, Quéguiner B (2005) MD145/KEOPS (Kerguelen: étude comparée de l'Océan et du Plateau dans les eaux de Surface) à bord du Marion Dufresne. Institut Polaire Français Paul Emile Victor, Cruise Report: OCE/2005/01, IPEV, Brest

Blain S, Tréguer P, Belviso S, Bucciarelli E and 8 others (2001) A biogeochemical study of the island mass effect in the context of the iron hypothesis: Kerguelen Islands, Southern Ocean. Deep-Sea Res I 48:163-187

Blain S, Quéguiner B, Armand LK, Belviso S and 43 others (2007) Effect of natural iron fertilization on carbon sequestration in the Southern Ocean. Nature 446:1070-1074

Crawford RM, Hinz F, Honeywill C (1998) Three species of the diatom genus Corethron Castracane: structure, distribution and taxonomy. Diatom Res 13:1-28

Crosta X, Romero O, Armand LK, Pichon JJ (2005) The biogeography of major diatom taxa in Southern Ocean sediments. 2. Open-ocean related species. Palaeogeogr Palaeoclimatol Palaeoecol 223(1-2):66-92

El-Sayed SZ, Fryxell GA (1993) Phytoplankton. In: Friedmann EI (ed) Antarctic microbiology. Wiley-Liss, New York, p 65-122

Eppley RW, Reid FMH, Strickland JDH (1970) The ecology of the plankton off La Jolla, California, in the period April through September, 1967. III. Estimates of phytoplankton crop, size, growth rate, and primary production. Bull Scripps Inst Oceanogr 17:33-42

Fiala M, Oriol L (1990) Light-temperature interactions on the growth of Antarctic diatoms. Polar Biol 10:629-636

Fryxell GA, Prasad AKSK (1990) Eucampia antarctica var. recta (Mangin) stat. nov. (Biddulphiaceae, Bacillariophyceae): life stages at the Weddell Sea ice edge. Phycologia 29:27-38

Garibotti IA, Vernet M, Kozlowski WA, Ferrario ME (2003)
Composition and biomass of phytoplankton assemblages in coastal Antarctic waters: a comparison of chemotaxonomic and microscopic analyses. Mar Ecol Prog Ser $247: 27-42$

Garibotti IA, Vernet M, Smith RC, Ferrario ME (2005) Interannual variability in the distribution of the phytoplankton standing stock across the seasonal sea-ice zone west of the Antarctic Peninsula. J Plankton Res 27(8):825-843

Hamm CE, Merkel R, Springer O, Jurkojc P, Maier C, Prechtel K, Smetacek V (2003) Architecture and material properties of diatom shells provide effective mechanical protection. Nature 421:841-843

Hasle GR (1969) An analysis of the phytoplankton of the Pacific Southern Ocean: abundance, composition and distribution during the Brategg expedition, 1947-1948. Hvalrad Skr Sci Results Mar Biol Res 52:1-168

Hasle GR (1978) Using the inverted-microscope method. In: Sournia A (ed) Monographs on oceanographic methodology 6. Phytoplankton manual. UNESCO, Paris, p 191-196

Hasle GR, Syvertsen EE (1997) Marine diatoms. In: Tomas CR (ed) Identifying marine phytoplankton. Academic Press, New York, p 5-361

Havskum H, Schlüter L, Scharek R, Berdalet E, Jacquet S (2004) Routine quantification of phytoplankton groups microscopy or pigment analyses? Mar Ecol Prog Ser 273: $31-42$

Hillebrand H, Dürselen CD, Kirschtel D, Pollingher U, Zohary $\mathrm{T}$ (1999) Biovolume calculation for pelagic and benthic microalgae. J Phycol 35:403-424

Jacques G, Descolas-Gros C, Grall JR, Sournia A (1979) Distribution du phytoplancton dans la partie Antarctique de l'Ocean Indien en fin d'été. Int Rev Gesamten Hydrobiol 64:609-628

Jeffrey SW, Hallegraeff GM (1980) Studies of phytoplankton species and photosynthetic pigments in a warm core eddy of the East Australian current. I. Summer populations. Mar Ecol Prog Ser 3:285-294

Jeffrey SW, Hallegraeff GM (1987) Phytoplankton pigments, species and light climate in a complex warm-core eddy of the East Australian current. Deep-Sea Res 34:649-673

Jeffrey SW, Mantoura RFC, Wright SW (eds) (2005) Phytoplankton pigments in oceanography. Guidel modern methods. Monographs on oceanographic methodology, Vol 10. UNESCO, Paris

Jordan RW, Ligowski R, Nöthing EM, Priddle J (1991) The diatom genus Proboscia in Antarctic waters. Diatom Res 6(1):63-78

Kang SH, Fryxell GA (1993) Phytoplankton in the Weddell Sea, Antarctica: composition, abundance and distribution in water-column assemblages of the marginal ice-edge zone during austral autumn. Mar Biol 116: 335-348

Kang SH, Kang JS, Lee S, Chung KH, Kim D, Park MG (2001) Antarctic phytoplankton assemblages in the marginal ice zone of the northwestern Weddell Sea. J Plankton Res 23: $333-352$

Karsten G (1905) Das Phytoplankton des Antarktischen Meeres nach dem Material der deutschen TiefseeExpedition 1898-1899. Otto Koeltz Science Publishers, Königstein

Kirschtel DB (1992) The effects of nutrient constraint on the development of a stream periphyton community. MS thesis. University of Louisville, KY

Klein B, Sournia A (1987) A daily study of the diatom spring bloom at Roscoff (France) in 1985. II. Phytoplankton pigment composition studied by HPLC analysis. Mar Ecol Prog Ser 37:265-275 
Kopczynska EE, Fiala M (2003) Surface phytoplankton composition and carbon biomass distribution in the Crozet Basin during austral summer of 1999: variability across frontal zones. Polar Biol 27:17-28

Kopczynska EE, Weber LH, El Sayed SZ (1986) Phytoplankton species composition and abundance in the Indian Sector of the Antarctic Ocean. Polar Biol 6:161-169

Krell A, Schnack-Schiel SB, Thomas DN, Kattner G, Zipan W, Dieckmann GS (2005) Phytoplankton dynamics in relation to hydrography, nutrients and zooplankton at the onset of sea-ice formation in the eastern Weddell Sea (Antarctica). Polar Biol 28:700-713

Manguin E (1954) Diatomés marines provenant de l'Ile Heard (Australian National Research Expedition). Rev Algolog (Nouvelle Sér) 1:14-24

Menden-Deuer S, Lessard EJ (2000) Carbon to volume relationships for dinoflagellates, diatoms, and other protist plankton. Limnol Oceanogr 45:569-579

Menden-Deuer S, Lessard EJ, Satterberg J (2001) Effect of preservation on dinoflagellate and diatom cell volume, and consequences for carbon biomass predictions. Mar Ecol Prog Ser 222:41-50

Moal J, Martin-Jezequel V, Harris RP, Samain JF, Poulet SA (1987) Interspecific and intraspecific variability of the chemical composition of marine phytoplankton. Oceanol Acta 10(3):339-346

Montagnes DJS, Franklin DJ (2001) Effect of temperature on diatom volume, growth rate, and carbon and nitrogen content: reconsidering some paradigms. Limnol Oceanogr 46(8):2008-2018

Montagnes DJS, Berges JA, Harrison PJ, Taylor FJR (1994) Estimating carbon, nitrogen, protein, and chlorophyll $a$ from volume in marine phytoplankton. Limnol Oceanogr 39(5):1044-1060

Morel FMM, Hudson RJM, Price NM (1991) Limitation of productivity by trace metals in the sea. Limnol Oceanogr 3: $1742-1755$

Moreno-Ruiz JL, Licea S (1995) Observations on the valve morphology of Thalassionema nitzschioides (Grunow) Hustedt. In: Marino D, Montresor M (eds) Proceedings of the 13th International Diatom Symposium. Maratea, Italy 1 to 7 th Sep 1994. Biopress Limited, Bristol, p 393-413

Moro I, Paccagnella R, Barbante C, Andreoli C (2000) Microalgal communities of the sea ice, ice-covered and ice-free waters of Wood Bay (Ross Sea, Antarctica) during the austral summer 1993-94. PSZN I: Mar Ecol 21(3-4): 233-245

Mullin MM, Sloan PR, Eppley RW (1966) Relationship between carbon content, cell volume and area in phytoplankton. Limnol Oceanogr 11:307-311

O'Meara E (1877) On the diatomaceous gatherings made at Kerguelen's Land by H.N. Moseley, M.A., H.M.S. 'Challenger'. J Linn Soc (Bot) XV:55-59, Plate I

Pakhomov EA, Ratkova TN, Froneman AP, Wassmann P (2001) Phytoplankton dynamics at the ice-edge zone of the Lazarev Sea (Southern Ocean) during the austral summer 1994/1995 drogue study. Polar Biol 24:422-431

Parsons TR, Stephens K, Strickland DH (1961) On the chemical composition of eleven species of marine phytoplank-

Editorial responsibility: Gerhard Herndl,

Den Burg, Texel, The Netherlands ters. J Fish Res Board Can 18:1001-1016

Priddle J, Jordan RW, Medlin LK (1990) Family Rhizosoleniaceae. In: Medlin LK, Priddle J (eds) Polar marine diatoms. British Antarctic Survey, Cambridge, p 115-127

Riaux-Gobin C, Romero O (2003) Marine Cocconeis Ehrenberg (Bacillariophyceae) species and related taxa from Kerguelen's Land (Austral Ocean, Indian sector). Bibl Diatomol 47:1-188

Sicko-Goad LM, Schelske CL, Stoermer EF (1984) Estimation of intracellular carbon and silica content of diatoms from natural assemblages using morphometric techniques. Limnol Oceanogr 29:1170-1178

Smayda TJ (1978) From phytoplankton to biomass. In Sournia A (ed) Monographs on oceanographic methodology 6 . Phytoplankton manual. UNESCO, Paris, p 273-279

Smetacek V, Klaas C, Menden-Deuer S, Rynearson TA (2002) Mesoscale distribution of dominant diatom species relative to the hydrographical field along the Antarctic Polar Front. Deep-Sea Res II 49:3835-3848

Smetacek VS, Assmy P, Henjes J (2004) The role of grazing in structuring Southern Ocean pelagic ecosystems and biogeochemical cycles. Antarct Sci 16(4):541-558

Smith REH, Stapleford LC, Ridings R (1994) The acclimated response of growth, photosynthesis, composition, and carbon balance to temperature in the psychrophilic ice diatom Nitzschia seriata. J Phycol 30:8-16

Snoeijs P, Busse S, Potapova M (2002) The importance of diatom cell size in community analysis. J Phycol 38: $265-272$

Stapleford LS, Smith REH (1996) The interactive effects of temperature and silicon limitation on the psychrophilic ice diatom Pseudonitzschia seriata. Polar Biol 16:589-594

Stramski D, Sciandra A, Claustre H (2002) Effects of temperature, nitrogen, and light limitation on the optical properties of the marine diatom Thalassiosira pseudonana. Limnol Oceanogr 47(2):392-403

Strathmann RR (1967) Estimating the organic carbon content of phytoplankton from cell volume or plasma volume. Limnol Oceanogr 12:411-418

Sullivan CW, Arrigo KR, McClain CR, Comiso JC, Firestone J (1993) Distributions of phytoplankton blooms in the Southern Ocean. Science 262:1832-1837

Suto I (2004) Coronodiscus gen. nov., a new diatom resting spore genus from the North Pacific and Norwegian Sea. Diatom 20:95-104

Suzuki Y, Takahashi M (1995) Growth responses of several diatom species isolated from various environments to temperature. J Phycol 31:880-888

Verity PG, Smetacek V (1996) Organism life cycles, predation, and the structure of marine pelagic ecosystems. Mar Ecol Prog Ser 130:277-293

Villareal TA, Fryxell GA (1983) Temperature effects on the value structure of the bipolar diatoms Thalassiosira antarctica and Porosira glacialis. Polar Biol 2:163-169

Wright SW, Jeffrey SW, Mantoura RFC, Llewellyn CA, Bjornland T, Repeta D, Welschmeyer N (1991) Improved HPLC method for the analysis of chlorophylls and carotenoids from marine phytoplankton. Mar Ecol Prog Ser 77: 183-196

Submitted: September 27, 2006; Accepted: May 4, 2007 Proofs received from author(s): July 17, 2007 